\author{
VITALII HURA, \\ Ukrainian Evangelical Seminary (Kyiv, Ukraine) \\ e-mail: guravit@gmail.com, ORCID 0000-0002-1207-3085
}

\title{
COMPARATIVE DISCOURSE ANALYSIS OF THE PRACTICS OF CHURCH WORSHIP OF UKRAINIAN AND AMERICAN PENTECOSTALS
}

The article demonstrates the basic concepts of discourse theory and offers a model of practical application of discourse analysis to determine the liturgical identity of the early American Pentecostals and Ukrainian Pentecostals of the Soviet period.

The author demonstrates that if there are common elements in the history of the origin of the Pentecostal movement and the similarity of the dogmatic basis, the causes of misunderstandings should be sought in the hermeneutics of liturgical discourse. The "apostolic discourse" of the early American Pentecostals tended to maximize the deconstruction of all forms of worship in order to maximize the revelation of human nature for the knowledge of God. The discourse of "biblical fidelity" of the Soviet Pentecostals was formed during the period of information isolationism and brutal persecution on religious grounds. Combined with the Baptist tradition of regulated worship and Eastern Orthodox ideas of spirituality, the Soviet Pentecostals formed their own local liturgical tradition.

The comparison of mystical manifestations and practices performed between the representatives of the Azusa Street Revival and the Soviet Pentecostals clearly illustrates the above theses.

Key word: discourse, theological discourse, religious discourse, liturgical discourse, Pentecostals, Azusa Street Revival, Ivan Voronaev.

\section{Introduction}

In 2021, all Ukrainian Pentecostals celebrate the anniversary of centenary of the beginning of missionary work of Ivan Voronaev (1885-1937). Ivan Voronaev received the Pentecostal doctrine about baptizing by Holy Spirit from Glad Tidings Tabernacle (NYC) and became of missioner of Assemblies of God. For eight years, Voronaev has estavlished near 1,000 churches and groups with more than 25,000 believers in USSR. During terrible period of information isolation of the Church in the USSR Voronaev's disciples developed own local theology which found expression in the liturgical discourse.

As well-known, in 1991, Ukraine proclaimed the independence and local pentecostals began to build "bridges of communications" with western organizations of pentecostals. Ukrainian period of freedom showed them that they have similar doctrines with the "Assembly of God of the United States" and "Church of God". But there was a noticeable difference between the US church stile of Sunday service and local church traditions of Ukrainian Pentecostal movement in the liturgical practice of worship and rituals.

The development of interdisciplinary researches open new methodological perspectives for modern researches in theological and religious studies. One of the promising areas is the use of methods of discourse analysis to study the theological identity and worldview matrix of the religious group, the influence of its theological ideas in society, the formation of value ideals, and so on.

The purpose of the article is to model the practical application of the methodology of discourse analysis of liturgical ritual forms to identify the church identity of the national Pentecostals.

\section{СХІД Том 1 (2) травень-червень 2021 р.}

To achieve this goal, the author performs the following three research tasks:

First, a definition of discourse in the light of historical context and modern linguistics will be proposed.

Second, the author will demonstrate examples of the use of the concept of discourse analysis in modern empirical theological research.

Third, we will consider the possibility of using discourse analysis to interpret the theological and liturgical identity of a religious group (on the example of the Pentecostal movement).

\section{Research methods}

For this research, we have used the method of discourse analysis, method of comparative analysis and the method of theoretical modelling.

\section{Result and Discussions}

Modern theory of discourse began to emerge in the middle of the twentieth century as an independent field of scientific knowledge based on works of Z. S. Harris, M. Heidegger, Paul-Michel Foucault, Jacques Derrida, Jürgen Habermas, Teun Adrianus Van Dijk, Louise Phillips and Marianne Jogrensen.

Among the modern authors of the post-Soviet space, the most significant are the works of V. Karasik (2002) and M. Makarov (2017).

The concept "discourse" is widely used today by various humanities like philosophy, philology, sociology and combines a number of controversial meanings. For this reason, first of all we have to clarify the concept of "discourse".

The term "discourse" was widely used in theology and philosophy to interpret epistemological principles, the first 
anthropological and social theories. In the twentieth century, two trends emerged in linguistics, which interpreted the concept of discourse differently. The first is known as "formalism" or "structuralism", and was characterized by the study of the abstract form of language and its structure. The second trend is "functionalism" and it is characterized by an interest in the purpose for which language is used. Representatives of these trends proposed their own definitions of discourse.

According to Deborah Cameron from University of Oxford, linguists' study of the language as the "system of systems" led to the first, most common formulation of term "discourse" as "language above a sentence". According to this definition, discourse analysis "seeks patterns and structure in elements that are broader than one sentence" (Cameron, 2015: 28).

The next definition of "discourse" is formulated as "language in action". Its means: "language used to do something or mean something", or "language is created and interpreted in the context of the real world".

Limiting the description of the evolution of the content of the concept of "discourse", we note that this concept has undergone significant development in linguistics in the works of Norman Fairclough and Teun van Dijk. The following definition was given: "... discourse is a complex communicative phenomenon that includes, in addition to the text, extralinguistic factors (knowledge about the world, purpose and addressee), which are necessary for understanding the addressee" (Khurmatullin, 2009). For Teun Van Dijk, "discourse must be understood as an action" or as "text in context" or "an event that must be described empirically" (van Dijk, 2013: 47).

M. Stubbs identifies three main characteristics of discourse: first, "discourse is a unit of language that is formally more than one sentence"; secondly: "in terms of content, the discourse is related to the use of language in a social context"; third, "the discourse must be dialogical and interactive in its organization" (Karasik, 2002: 189).

Interactivity of intertextuality is the basis of the methodology of discourse analysis. After all, "texts do not have meanings in themselves; they make sense only in the process of interaction with other texts, the discourses with which they are associated, the ways of their production, "scattering" and consumption. Discourse analysis is aimed at studying how texts acquire meaning in these processes, as well as their role in the construction of social reality in the process of creating meanings" (Phillips \& Hardy, 2002).

In conducting a discourse analysis, M. Halliday proposed to accept social interaction as the "central unit of research". Which means, for M. Halliday: "everything is a text that matters in a certain situation"; and "the text means a continuous process of semantic choice" (Tycher et al., 2017: 52).

Jay Lemke as expert at discourse analysis argues that "we speak with the voices of our societies, and to the extent that we have individual voices, we shut them out of the social voices that ares available to us. We are appropriating the words of others to express one's own word" (Cameron, 2015: 35). D. Cameron notes, "discourse analysis can be seen as a method of studying the 'social voices' available to people whose language is collected by analysts" (Cameron, 2015: 36).

In summary, discourse analysis has become an alternative approach to the study of language and relations in society, exploring the influence and power of language (Cipriani, 2002: 3).

Karasik distinguishes several types of discourse: domestic, artistic, scientific, business, philosophical, religious, political, and even advertising and computer. That is, discourse is formed in the speech act as an interaction between actors in various information fields (Karasik, 2002: 41-66).

The study of religious discourse deepens mutual understanding of dialogue partners in modern society. Stephen T. Davis (1997) has completed the study of religious discourse in various forms of its interaction. K. Sandnes (2016) prepared research of early Christian discourse of Christ's prayer in Gethsemane.

The subject of the study of religious and theological discourses can be any sacred text that is an expression of worship. For examples a sermon, a song, a prayer or a sacred ritual (liturgy). The study of theological discourse allows a researcher to conduct empirical research in theology.

An important example of the application of the methodology of discourse analysis in religious and theological research is a collection of works edited by Hans Schilderman "Discourse in Ritual Studies" (2007). The proposed publication is an example of an empirical approach to the study of theology. The authors focused on the study of liturgical forms of the Roman Catholic Church in three perspectives: theoretical, empirical and hermeneutic.

Hans Schilderman emphasizes that the liturgy always attracts the attention of researchers, because it is an outward manifestation of the public worship of the Church and the practice of community faith conducted according to the precepts of formal conduct. The researcher argues that any religion becomes known through its public representation. Historically, the liturgical model has become the embodiment of the Church's faith and the expression of Christian dogmas. In relation to practical Christian life, fidelity to the liturgical tradition is equated with fidelity to God. Therefore, the discourse analysis of liturgical church rituals opens a new level of understanding of the role of the church and its relationship with society in the spheres of human dignity, freedom and justice (Schilderman, 2007: 76).

The proposed methodology for analyzing the liturgy of the Roman Catholic Church can be applied to the study of the identity of Pentecost.

The modern Pentecostal movement has become one of the most dynamic components of world Christianity during 120 years of its development. According to Alistair McGrath, "Today, Pentecost in its various forms is the largest single Christian community since Catholicism and outnumbers all other forms of Protestantism combined" (McGrath, 2017: 575).

It is important to note that the analysis of the names of the various Pentecostal associations demonstrates the dynamics of attempts to be identify with the Apostolic Church of the New Testament. For example, the first Pentecostal communities under the leadership of Charles F. Parchem was called "Apostolic Faith Groups." Later, in the process of institutionalizing religious communities, the name "Assembly of God" and "Church of God" appeared in the United States. The Ukrainian Pentecostals adopted the name "Christians of the Evangelical Faith" in accordance with biblical texts (Acts 11:26 and Philip 1:27). "Philadelphia" is also popularly known among European Pen- 
tecostals as an indication to the Church that, according to the position of dispensationalism, it will be picked up before the Great Tribulation Period. Thus, biblical allusions and direct nominations used for naming Pentecostal denomination, have to demonstrate own historical connection with the apostolic experience of receiving the Holy Spirit. The use of these names is intended to demonstrate value to a group of biblical teachings and biblical experiences as opposed to the theological tradition of historical churches.

Also, the World Pentecostal movement shaped its self-perception through the discourse of the reception of the biblical metaphors of "fire" (Luke 12:49) and "late rain" (Joel 2: 28-32). These metaphors had to describe the dynamics of the spread of this denomination in the world.

A. McGrath described of the essence of the Pentecostal doctrine in four sentences:

"From this point of view, Jesus Christ is:

1. Savior who gives us freedom from sins.

2. Healer who delivers us from disease and authority of Satan.

3. The Baptist in the Spirit who enables ordinary believers to bear witness to the gospel to the end of time.

4. The coming King who is preparing the way within the church for his future return in glory" (McGrath, 2017: 589).

Thus, the general world Pentecostal discourse is defined by the four Christological theses that Christ is the Savior, the Healer, the Baptist in the Spirit, and the Coming King. Although the Pentecostal movement demonstrates total unity of understanding this four sentences and need all members to have personal experience of glossolalia, in the world Pentecostalism is represented by a wide variety of forms of worship at more than 11000 denominations. Therefore, in order to interpret the local Pentecostal identity, it is important to focus on the hermeneutics discourses of liturgical rituals as markers of confessional identity.

Studying the liturgical discourse, we note that all Pentecostals in the World recognize two obligatory sacraments: the baptism in water and the Lord's Supper.

"Most Protestant groups agree that Christ left to the Church two rituals that should be part of Christian worship: water baptism and the Lord's Supper" (Horton, 1994: 796). That is mandatory practice for American and Ukrainian Pentecostals.

In different Pentecostal Churches, some details of these sacred rituals may be little bit different and depend from type of culture. However, the common core is understanding these rituals as proclaim act of received new life in baptizing and blessing in prayer with the bread and grape wine (or juice) as symbols of unity the Body of Christ.

Voronayev's followers in Ukraine celebrate the Lord's Supper with the unleavened bread and red grape wine. Before the Eucharist, they must do the rite of washing feet according to text of John.13.

Another branch of the Ukrainian Pentecostals does not practice rite washing feet before Lord's Supper, and usually they use leavened bread and gripe wine for the Lord's Supper. According to the decision of the local Church, they may use even Jewish matzo and grape juice.

The pandemic caused by the COVID-19 virus has sparked a wide-ranging debate about the admissibility of the use of individual cups for the Lord's Supper and even the possibility of doing it online. Also, among Slavic pentecostals, a lot of time was spent for discussion about right of non-ordained church members to do Lord's Supper for own family. As a result of the discussions, the discourse of "faithfulness to the Bible" was actualized among the more conservative churches. As a result, they made a rule for rite of the Lord's Supper to do it in the maximum accordance with the Biblical description. In practice, its mean that only ordinary ministers can do the Lord's Supper with only one common cup for real live meeting. Other Pentecostal Churches, with more labile thinking, quickly adapted to the new conditions without risking the lives of their parishioners. The issues raised have not changed the general Pentecostal discourse, according to which the main message of these two rituals was to receive new life through identification with Christ and the unity of the Body of Christ in remembrance of Christ's sufferings.

Most Pentecostal churches around the world practice other rituals. For example, the ordination of new pastors for the ministry is conducted through the ritual of "the laying on of hands" by the church leaders. Also with church wedding and pastor's prayer of blessing, every new Christian family begins.

In the liturgical practice of the Ukrainian Pentecostals, there are additional elements borrowed from the practice of historical churches (Orthodoxy and Catholicism). For example, we can mention regular confession of sins to a church priest, prayer with the oil anoint (James 5:14), prayer for newborns babies in the church, and funeral services. The form of these church rituals depends on the particular area and is designed to fill the Christian content of most stages of Christian life. Some Ukrainian Pentecostals propose recognizing 7 sacred rituals as sacraments of the church, unconsciously following the practice of the Orthodox Church and moving away from the theses of the European Reformation. These additional rituals are close and understandable for the pupils of the Eastern Orthodox culture and are incomprehensible for the representatives of the Western Protestant culture.

It is important to note that the Pentecostals from the Azusa Street in 1906 understand themselves as the last generation of Christians before the second coming of Christ in Glory. The main purpose of the existence of the community of "Apostolic Faith" was recognized as the World Mission of preaching the Gospel. Therefore, during the Azusa Street Revival, everything without the direct biblical prescription was rejected. Moreover, the new Pentecostal discourse was formed of the influenced by the tendency to total deconstruction of obsolete forms of worship. The liturgical discourse on Azusa Street demonstrates a longing for the ideal of the Apostolic Church model than is represented at the text of the New Testament. In fact, the awakening on Azusa Street Revivals was a proclamation of the values of the early Christian Church: freedom of worship, simplicity, equality before God in the common priesthood. For this reason, the nature of their worship practices, contrary to the existing laws on segregation, showed openness to all parishioners, recognizing the equality of all nations.

During decades of Soviet persecution, the Ukrainian Pentecostals made every effort to unify religious and liturgical provisions.

The proposed table below shows us the comparison of the practice of behavior of the American Pentecostals 
Table 1. - Comparison of liturgical practice of Azusa Street Revival (1906) and Ukrainian pentecostals in USSR

\begin{tabular}{|c|c|c|}
\hline \# & $\begin{array}{c}\text { Azusa Street Revival } \\
\text { USA (1906) }(\text { Robek, 2011) }\end{array}$ & $\begin{array}{l}\text { Ukrainian pentecostals at USSR } \\
(1921-1991)\end{array}$ \\
\hline 1 & $\begin{array}{l}\text { Speaking and singing with tongues and prophecy } \\
\text { ("glossolalia") }\end{array}$ & All of them accepted it \\
\hline 2 & Writing texts in "other languages" & Unknown practice \\
\hline 3 & Fall down "under the influence of the Spirit" & Forbidden \\
\hline 4 & $\begin{array}{c}\text { "Holy rolling" on the floor under the influence of the } \\
\text { Spirit" }\end{array}$ & Forbidden \\
\hline 5 & $\begin{array}{c}\text { "Holy laughter" ( }{ }^{*} \text { this phenomenon is better known } \\
\text { as the "Toronto Blessing") }\end{array}$ & Forbidden \\
\hline 6 & Dancing movements during Worship & Forbidden \\
\hline 7 & $\begin{array}{l}\text { Applause as an element of expression } \\
\text { of worship of God. }\end{array}$ & Forbidden \\
\hline 8 & $\begin{array}{l}\text { The use of specific musical motifs of African Ameri- } \\
\text { cans }\end{array}$ & The use of modern music for worship was forbidden \\
\hline 9 & $\begin{array}{c}\text { Worship of God in singing and with musical accom- } \\
\text { paniment. }\end{array}$ & Depended on the region \\
\hline 10 & Spontaneity in the sermon, and testimony. & Depended on the region \\
\hline 11 & Ordination of women to pastoral ministry & Forbidden \\
\hline
\end{tabular}

From the given table, it is clear that the Churches from USSR strictly forbad all mystical practices of the early Pentecostals ("fall down", "Rolling on the floor", "holy laughing" and others), of course, except ащк the practice of "glossolalia" as a Gift of Holy Spirit. As well known, for Ukrainian churches, the order of worship and sermon was regulated according tradition of a Baptist churches in USSR. It becomes clear that Voronaev's followers rejected almost all the mystical actions that were present in the churches at the United States.

The modern liturgical discourse of the Ukrainian Pentecostals, communicated through liturgical practice and preaching, is to preserve the "holiness" and "righteousness" of the Church as the "bride of Christ" (Ps. 44/45). Of course, the process of forming the content of "holiness", "righteousness" and "piety" was influenced by the context of Eastern Orthodox spirituality. In this way, "the apostolic" discourse of the early Pentecostals was transformed into the local discourse of "fidelity to the truth" of the Ukrainian Pentecostals of USSR. In practical sphere, certainly the lack of understanding of the nature of the formation of the American missionary Pentecostal discourse leads to misunderstanding between Ukrainian and American forms of worship.

According the table, the American and Ukrainian Pentecostals, having a common history and similar doctrines, formed a different liturgics discourse, which led to the closure of local theological churches for cooperation with American missionaries. Therefore, when interpreting the liturgical forms of American and Ukrainian Pentecostals, it is necessary remembering the local context of development of each church group, which influences the formation of liturgical discourse.

\section{Conclusions}

Examining the concept of "discourse" in the light of historical context and modern linguistics, it was found that "discourse should be understood as an action" or "an event that must be described empirically". Accordingly, the Pentecostal movement was formed in the discourse of realizing its own mission in the revival of the apostolic faith.

The use of the concept of discourse analysis in modern empirical theological research was demonstrated on the example of the study of rituals of the liturgy of the Roman Catholic Church.

Using a comparison of American and Ukrainian Pentecostals, a parallel analysis of two liturgical discourses was conducted, revealing the reasons why local theological groups did not accept American missionaries, despite the common dogmatic basis.

Thus, a modeling of the practical application of the methodology of discourse analysis of liturgical ritual forms was performed to identify the church identity of the national Pentecostals.

\section{REFERENCES}

Cameron, D. (2015). Conversational discourse [transl. from Eng]. Kharkov: Gumanitarnyy tsentr (In Russian).

Cipriani, Andreia Cristina (2002). Power in religious discourse: a discourse analysis of two sermon from the Universal Church of the Kingdom of God. Universidade Federal de Santa Catarina.

Davis, Stephen T. (1997). Philosophy and Theological Discourse. London: MACMILLAN PRESS LTD.

Horton, Stanley (1994). Systematic Theology: Revised Edition Paperback. Gospel Publishing House.

Karasik, V. I. (2002). Yazykovoy krug: lichnost, kontsepty $i$ diskurs. Volgograd: Peremena (In Russian). 
Khurmatullin, A. K. (2009). Ponyatiye diskursa v sovremennoy lingvistike. Uchenyye zapiski Kazanskogo universiteta. Seriya Gumanitarnyye nauki, 151 (6), 31-37. https://cyberleninka.ru/article/n/ponyatie-diskursa-vsovremennoy-lingvistike (In Russian).

Makarov, M. L. (2017). Osnovy teorii diskursa. ITDGK "Gnozis" (In Russian).

McGrath, Alistair (2017). Dangerous idea of Christianity [transl. from Eng]. Kyiv: Dukh I Litera (In Ukrainian).

Phillips, Nelson \& Hardy, Cynthia. (2002) What Is Discourse Analysis? In N.Phillips and C.Hardy Discourse Analysis: Investigating Processes of Social Construction. Thousand Oaks, CA: Sage. PP. 1-18. http://discourseanalysis.org/ada1/st4.shtml .

Віталій Гура,

Украӥнська євангельська семінарія (м. Київ, Украӥна)

e-mail: guravit@gmail.com,ORCID0000-0002-1207-3085

\section{ПОРІВНЯЛЬНИЙ ДИСКУРС-АНАЛІЗ ПРАКТИКИ ЦЕРКОВНОГО ПОКЛОНІННЯ УКРАЇНСЬКИХ ТА АМЕРИКАНСЬКИХ П'ЯТИДЕСЯТНИКІВ}

Стаття демонструє основні поняття теорії дискурсу та пропонує модель практичного застосування дискурс-аналізу для визначення літургійної ідентичності ранніх американських п'ятидесятників та українських п'ятидесятників радянського періоду. Показано, що при наявності спільних елементів в історії зародження п'ятидесятницького руху та подібності догматичної бази причини непорозумінь потрібно шукати у герменевтиці богослужбового дискурсу. «Апостольський дискурс» ранніх американських п'ятидесятників тяжів до максимальної деконструкції усіх богослужбових форм із метою максимального розкриття єства людини для пізнання Бога. Дискурс «Біблійної вірності» радянських п'ятидесятників був сорормований у період інформаційного ізоляціонізму і жорстоких переслідувань за релігійними ознаками. У поєднанні із баптистською традицією регламентованого богослужіння та східно-православними уявленнями про духовність, радянські п'ятидесятники сформували власну локальну літургійну традицію. Проведене порівняння містичних проявів і практик між представниками пробудження Азуза-Стріт та радянськими п'ятидесятниками наочно ілюструє наведені тези.

Ключові слова: дискурс, богословський дискурс, релігійний дискурс, літургійний дискурс, п'ятидесятники, Пробудження на Азуза-Cmpim, Іван Воронаєв.

(c) Vitalii Hura

Надійшла до редакції: 05.05.2021

Прийнята до друку: 22.06.2021 